\title{
Attitude towards Career Choices among Graduating PharmD Students at College of Pharmacy, Qassim University
}

\author{
Mugahid A Mobark ${ }^{1}$, Mustafa S Saeed ${ }^{2}$, Fahad S Almotairi ${ }^{3}$, Haifa AL-Dhawyan ${ }^{4}$ \\ ${ }^{1}$ Assistant Professor, Department of Pharmacy Practice, College of Pharmacy, Qassim University, KSA \\ ${ }^{2}$ Lecturer, Department of Pharmacy Practice, College of Pharmacy, Qassim University, KSA \\ ${ }^{3,4}$ PharmD student, College of Pharmacy, Qassim University, KSA
}

\begin{abstract}
Background: The career opportunities for pharmacists have expanded as the health care has developed. Recently the career choices have included several fields such as hospital practice, community pharmacy, industrial field, academia, research and administrative pharmacy. Objective: This study evaluated the pattern andinfluencing factors of future carrier choices with an aim to effectively target career advices to the graduating students.Methods: An observational, cross sectional study was conducted among graduating PharmD students at the college of pharmacy, Qassim University, KSA from March to April 2018. A total of 238PharmD students were included. Descriptive and inferential statistics were used in the analysis of data. Results: The study showed the graduating male (51.3\%) were slightly higher than female (48.7\%). The overall mean age of students was 24 years. The internet media and electronic newspapers were the most common sources of information regarding the available career choices. Hospital field as a Future career was the most preferred (55.46\%). It was found that personal interest (20.9\%), high salary (18.4\%) and opportunities for development (13.7\%) were the main factors that influence career choices. Generally, the students have positive attitude towards pharmacy profession and more than (50\%) of students would like to continue postgraduate study in pharmacy. Conclusion: Most of participants were satisfy with pharmacy profession and the hospital field was the most preferred choice and personal interest was largely considered as influencing factor.
\end{abstract}

Keywords: Attitude, career, choices, PharmD, student

\section{Introduction}

Pharmacists are essential participants within the health-care unit. During the last two decades, considerable changes in pharmacy practice had occurred in terms of reprofessionalization, a renewal of patient focus and the development of approaches, tools and competencies to provide direct patient care [1]. In consistence with these changes, PharmD degree integrates more pharmacy practice and clinical pharmacy courses to target this goal [2]. Saudi Arabia suffers from a shortage of qualified practitioners and academic personnel. According to the Saudi Arabia Manpower Council, at least 17,000 pharmacists are needed by 2026 [3]. If pharmacy is unable to meet the needs of patients, the gaps in patient care could continue to increase. The bright side in this situation is that students in pharmacy schools can expect many job opportunities for the next several years [4]. Saudi Arabia opened several new programs to increase the number of national graduates. PharmD programs are now offered in the majority of pharmacy schools available for both genders to handle the need for advanced practitioners [3]. During the last 40 years; expansion in the colleges of pharmacy to more than twenty colleges had occurred, these colleges graduate almost more than 600 pharmacists per year with a bachelor degree of pharmacy and doctor of pharmacy [5].It'sof utmost importance for pharmacy programs to emphasize the motivational factors that influence students' choice of future career. Student's decision to choose a future career is one of difficult choices, they have to live with its consequences the rest of their lives. Socialization into pharmacy with course material, contact with teachers and work experience or practice placements helped students to make a more appropriate decision [6].A wide variety of factors are likely to influence the career choices of pharmacy undergraduates. Such factors may include: their passion to serve community and patients, the aspiration to conduct pharmaceutical research, the desire to develop new medicines, the satisfaction towards job security, the attraction towards financial rewards, flexibility of working hours and availability of any good opportunity [7]. Laney et al., reported that job environment was the most important factor for pharmacy students when they were deciding to start their professional life [8]. According to this it's important that students should receive sufficient information and adequate experience to enable them to make an informed choice. It is aimed that by more understanding of factors that influence pharmacy students' career choices, it may be clear to target career advice more effectively and appropriately.

\section{Material and Methods}

An observational, cross sectional study was conducted among graduating PharmD students at the college of Pharmacy, Qassim University in KSA. The study was carried out from March to April 2018. A total of 238 graduating PharmD students were included in this study and 16 participants were excluded as they felt to choose the appropriate choice stated in inverted question. A selfadministered questionnaire designed in English languish and constructedbased on previously published studies by Hasan et al.; Mohammad, Saad and Sumbal; Beedemariam et al. $[1,9,10]$. Face validity and inverted question were used to validate the questionnaire. The questionnaire was

\section{Volume 8 Issue 3, March 2019}


ethically approved by the local research committee of the of college of pharmacy, Qassim University and it was distributed online using SurveyMonkey website. It was consisted of 3 parts. The first part of the questionnaire included the socio-demographic characteristics of the participants. The second and third included questions regarding knowledge about career choices followed by questions related to attitude as students' preference among career choices available, the influences that affect their selection of career, the effect of future expectation on their current performance and satisfaction about pharmacy career. The data collected was analysed using Statistical Package for Social Sciences software (SPSS v.23) program. Descriptive analysis (frequencies, percentages) and Chisquare test were used for the analysis of data and $\mathrm{p}$ value of $<0.05$ was considered significant.

\section{Results}

Among a total of 238 participants the Sociodemographic characteristics showed thatthe percentage of male was slightly more than that of female, the mean age of participants was 24 years and the vast majority of them were single (Table-1). Regarding the source of information about the available career choices, the internet media and electronic newspaper were the most common source of information $(151 ; 37.01 \%)$. The senior pharmacists werethe second source of information $(109 ; 26.7 \%)$ the third source was conference and workshops $(92 ; 22.55 \%)$. The fourth source was the College's academic advisor (43; 10.54\%). There was no significant association between the gender and sources of information regarding the available career choices $(\mathrm{p}=0.350)($ Table-2). About the future field they prefer to work in, the hospital field of pharmacy was preferred by more than half of the participant $(132 ; 55.46 \%)$, the academic field was preferred by 24 participants $(10.08 \%)$, the pharmaceutical industries and the pharmaceutical companies were preferred by 20 participants $(8.4 \%)$ for each field. The community pharmacy was selected by only 5 participants $(2.10 \%)$ and the regulatory affairs and enrolment in future study were preferred by 4 participants (1.68\%) for each field. However, 23 participants $(9.66 \%)$ were not sure yet about the future field and 6 participants $(2.52 \%)$ preferred other field than pharmacy, there was no significant association between the gender and the preferred future career $(\mathrm{p}=0.131)$ (Table-3). Regarding the factors that influence career choices, the study found that personal interest was the most influencing factor(20.9\%) followed by High salary (18.4\%), opportunities for development (13.7\%), available job opportunities (11.8\%), previous training experience (9.7\%), job security (9.6\%), less working load $(6.7 \%)$ and someone attractedthem to the field $(4.5 \%)$ whilethe Family interest presented only in $4.4 \%$ (Figure-1). Regarding the students' Satisfaction about pharmacy profession $63 \%$ of the female significantly agreed or strongly agreed that they will select the same pharmacy profession if they have to make the choice again while $44.3 \%$ of male agreed with this with a significant gender variation $(\mathrm{p}<0.05) .74 .37 \%$ of participants were proud of pharmacy career and $62.61 \%$ of participants were happy that they have entered pharmacy schoolwith no significant gender difference found $(\mathrm{p}>0.05)($ Table-4).

\section{Discussion}

This study disclosed valuable information regarding knowledge and attitude about career choices among graduating PharmD students in the College of Pharmacy, Qassim University. It showed that the internet media and electronic newspaper were the most common source of information regarding the available career choices mentioned. This was explained by the wide use of internet and electronic newspaper beside various social media and electronic health services that are more easily accessible to the public. In a study done by Giordano, C. and Giordano, C. Showed that students prefer online media as their primary source of information [11].

Regarding students' future field preference, more than half of them preferred the hospital field and the personal interest was largely influencing their future career preference. In fact, the hospital pharmacy practice in Saudi Arabia is considered as one of the most advanced and developed practices in the region. In a national study conducted by Aljedai, et al. showed that most Saudi pharmacists preferred practicing in hospital settings, rather than the community pharmacy, because of higher salary and better job satisfaction [2]. Hasan et al. did study in Malaysian pharmacy students and showed that the majority (67.1\%) of students have chosenthe hospital pharmacy as a work setting upon graduation, which agreed with our result [1]. An Other study conducted at the University of Jordan by Abdelhadi et al. also reported a future aspiration of PharmD students to work as hospital clinical pharmacists [12].Academia was the second preferred career field mentioned by the female students. Opportunities for professional advancement and as mentioned by as Sheaffer et al., the ability to shape the future of pharmacy, personal flexibility, autonomy of faculty positions and the uniqueness of the academic environment were the motivators of pharmacy students interested in a career in pharmacy academia [13].

In this study the pharmaceutical industry was only mentioned by $8.40 \%$ of the participants. In fact, this is expected due to little number of pharmaceutical industries in Qassim region. In addition to that weakness of connection between the college pharmD and the pharmaceutical industries might have added to this low preference. In comparison with NnamdiAzikiwe University, a significantly greater percentage of pharmacy students have preferred the industrial field and this was hugely influenced by the large number of pharmaceutical industries and importation companies in the environment of Nnamdi Azikiwe University [14].

The community pharmacy was the least area of choice $(2.10 \%)$ by the participants. In a study conducted by Aljedai, et al. the result showed thatSaudi pharmacists tend to avoid the community setting because the payment is not as good as in other settings beside less job satisfaction. Furthermore, there is lack of electronic documentation and patient records in the community pharmacy practice field [2]. In contrast to our result, Machado et al., found that $33 \%$ of the graduating class and $27 \%$ of the upcoming class planned to practice in a community setting, while $18 \%$ of the graduating class and $24 \%$ of the upcoming class planned to

Volume 8 Issue 3, March 2019 www.ijsr.net 


\section{International Journal of Science and Research (IJSR) \\ ISSN: 2319-7064}

Impact Factor (2018): 7.426

work in a hospital setting [15].

The present study also aimed to explore the influencing factors on future career choices of graduating PharmD students. Personal interest $(20.9 \%)$ was the most factors that influenced the career choices of the graduating PharmD students, followed by high salary $(18.4 \%)$ then opportunities for development $(13.7 \%)$. This however manifests that while income may be important; these students are seriously looking at their future. When the choice of work is based on personal interests, this can help to work even in a desirable place. If student enjoy in the work, then they will feel motivated to keep the job and can attain successful career. A similar study in University of Peshawar was done by Saad et al., showed that the most important factor that influences the student choice of their career was also personal interest [9]. In contrast to these, Study on pharmacy students at the King Saud University in Riyadh conducted by Saleh et al., found that the most important influencing factors were salary and work environment; each factor reported by $77.3 \%$ of students [16]. Savage, et al., in Samford University, United States, found that work environment is a highly important job consideration in a pharmacy career [17].Traynor and Sorensen, found that the strongest influence on job choice after graduation was also workplace environment, followed by professional satisfaction and geographical location [18]

The present study also measured the students' satisfaction about pharmacy profession. In general, most participants have positive attitudes regarding the pharmacy profession. It was found that more than $(50 \%)$ were agreed or Strongly agreed that they would select the same pharmacy profession if they had to make the choice again. These results were consistent with the findings of Chumney EC, et al., as they stated that students indicated a high overall level of satisfaction with the PharmD program [19]. This study also showed that $74.37 \%$ of the participants were proud of pharmacy career and $62.61 \%$ of participants were happy that they have entered pharmacy school. In a study inUniversity of Jordan by Abdelhadi $\mathrm{N}$, et al.largely agreed with this study as 55\% stated that they are currently happy with studying PharmD [12].

\section{Conclusion}

This study adds value and support to the existing research looking at the motivation and influencing factors for students to select the appropriate future career choice after graduation. The present study indicated that hospital field was the most preferred career choice and the personal interest was the most important influencing factor that directs the future career choice. Most participants had positive attitudes beside significant self's satisfaction regarding pharmacy profession. Effectively emphasizing the future career choices in the educational program can help students to remain competitive in a challenging and developing their professional skill.

\section{Future Scope}

The educational program direction significantly influences the career choices so more emphasis in future career choices may be critical in shaping the future career selections of students.

In PharmD programthe conduction of several visits, organizing orientation sessions into pharmaceutical companies will more expose the students to this important pharmacy field.

\section{References}

[1] Hasan SS, Kwai Chong DW, Ahmadi K, Se WP, Hassali MA, Hata EM, Hadi MA, Sridhar SB, Ahmed SI, Yean LB, Efendie B. Influences on Malaysian pharmacy students' career preferences. American journal of pharmaceutical education. 2010 Sep;74(9):166.

[2] Al-jedai A, Qaisi S, Al-meman A. Pharmacy practice and the health care system in Saudi Arabia. The Canadian journal of hospital pharmacy. 2016 May;69(3):231.

[3] Kheir N, Zaidan M, Younes H, El Hajj M, Wilbur K, Jewesson PJ. Pharmacy education and practice in 13 Middle Eastern countries. American journal of pharmaceutical education. 2008 Sep;72(6):133.

[4] Keshishian F, Brocavich JM, Boone RT, Pal S. Motivating factors influencing college students' choice of academic major. American Journal of Pharmaceutical Education. 2010 Sep;74(3):46.

[5] Alomi YA. National Pharmacy Administration Programs at Ministry of Health in Saudi Arabia. BAOJ Pharm Sci. 2015 Sep 22;1(9).

[6] Wilson K, Jesson J, Langley C, Hatfield K, Clarke L. Pharmacy undergraduate students: career choices and expectations across a four-year degree programme. London: Royal Pharmaceutical Society of Great Britain. 2006 Aug:74-93.

[7] Shakeel S, Iffat W, Yasmin R, Ali H. Prospective career preferences of imminent pharmacist. IOSR J Pharm. 2013;3(8):38-43.

[8] Savage LM, Beall JW, Woolley TW. Factors that influence the career goals of pharmacy students. American journal of pharmaceutical education. 2009 Sep;73(2):28.

[9] Saad S, Sumbal A, Mohammad I. Attitude of fourth year Doctor of Pharmacy students towards pharmacy profession and their career preferences. Archives of Pharmacy Practice. 2012 Oct 1;3(4):293.

[10] Beedemariam G, Ebro M, Ageze H, Weldegerima B, Legesse B, Tilahun G. Pharmacy students' attitude and future career choices: a survey of four public schools of pharmacy in Ethiopia. Ethiopian Pharm J. 2014;30(1):57-63.

[11] Giordano C, Giordano C. Health professions students' use of social media. Journal of allied health. 2011 Jun 10;40(2):78-81.

[12] Abdelhadi NN, Wazaify M, Elhajji FW, Basheti IA. Doctor of Pharmacy in Jordan: Students' Career Choices, Perceptions and Expectations. Journal of Pharmacy and Nutrition Sciences. 2014 Aug 14;4(3):213-9.

[13] Sheaffer EA, Brown BK, Byrd DC, Gupchup GV, Mark SM, Mobley Smith MA, Rospond RM. Variables impacting an academic pharmacy career choice. 


\section{International Journal of Science and Research (IJSR) \\ ISSN: 2319-7064}

Impact Factor (2018): 7.426

American journal of pharmaceutical education. 2008 Sep;72(3):49.

[14] Ubaka CM, Ochie UM, Adibe MO. Student pharmacists' career choices: a survey of three Nigerian schools of pharmacy. Pharmacy practice. 2013 Jul;11(3):149.

[15] Machado C, Zapantis A, Singh-Franco D, Marsh WA, Beckey C. Effect of faculty-mediated interventions on pharmacy students' pursuit of postgraduate training. American Journal of Health-System Pharmacy. 2008 Jan 15;65(2):158-63.

[16] Saleh GB, Rezk NL, Laika L, Ali A, El-Metwally A. Pharmacist, the pharmaceutical industry and pharmacy education in Saudi Arabia: a questionnaire-based study. Saudi Pharmaceutical Journal. 2015 Oct 1;23(5):573-80.

[17] Savage LM, Beall JW, Woolley TW. Factors that influence the career goals of pharmacy students. American journal of pharmaceutical education. 2009 Sep;73(2):28

[18] Traynor AP, Sorensen TD. Student pharmacist perspectives of rural pharmacy practice. Journal of the American Pharmacists Association. 2005 Nov 1;45(6):694-9.

[19] Chumney EC, Ragucci KR. Student satisfaction and academic performance in a dual PharmD/MBA degree program. American journal of pharmaceutical education. 2006 Sep;70(2):29.

\section{Author Profile}

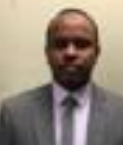

Dr. Mugahid A. Mobark, Assistant Professor, Department of Pharmacy Practice, College of Pharmacy, Qassim University, KSA

Mr. Mustafa S. Saeed, Lecturer, Department of Pharmacy Practice, College of Pharmacy, Qassim University, KSA

Fahad S Almotairi, PharmD graduate, College of Pharmacy, Qassim University, KSA

Haifa AL-Dhawyan, PharmD graduate, College of Pharmacy, Qassim University, KSA

\section{Tables and Figures}

Table 1: Sociodemographic characteristics of the study population $(\mathrm{n}=238)$

\begin{tabular}{|c|c|c|c|}
\hline \multicolumn{2}{|c|}{ Characteristic } & Number & $\%$ \\
\hline \multirow{2}{*}{ Gender } & Male & 122 & 51.3 \\
\cline { 2 - 4 } & Female & 116 & 48.7 \\
\hline \multirow{3}{*}{ Age } & From 22 to 23 years & 67 & 28.2 \\
\cline { 2 - 4 } & From 24 to 25 years & 134 & 56.3 \\
\cline { 2 - 4 } & 26 years and above & 37 & 15.5 \\
\hline \multirow{2}{*}{ Marital status } & Single & 221 & 92.9 \\
\cline { 2 - 4 } & Married & 17 & 7.1 \\
\hline
\end{tabular}

Table 2: The sources of information about the available career choices $(\mathrm{n}=238)$.

\begin{tabular}{|c|c|c|c|c|c|c|c|}
\hline \multirow{2}{*}{ Sources } & \multicolumn{5}{c|}{ Gender } & \multicolumn{3}{|c|}{ Total } & \multirow{2}{*}{ P-value } \\
\cline { 2 - 7 } & \multicolumn{3}{|c|}{ Male } & Female & $\%$ & \\
\cline { 2 - 7 } & $N$ & $\%$ & $N$ & $\%$ & & \\
\hline $\begin{array}{c}\text { The College } \\
\text { academic advisor }\end{array}$ & 30 & 13.9 & 13 & 6.8 & 43 & 10.54 & \\
\hline $\begin{array}{c}\text { Conferences and } \\
\text { workshops }\end{array}$ & 45 & 20.8 & 47 & 24.5 & 92 & 22.55 & \\
\hline $\begin{array}{c}\text { Internet media } \\
\text { and electronic } \\
\text { Newspaper }\end{array}$ & 73 & 33.8 & 78 & 40.6 & 151 & 37.01 & \multirow{2}{*}{0.350} \\
\hline $\begin{array}{c}\text { Senior } \\
\text { pharmacists }\end{array}$ & 60 & 27.8 & 49 & 25.5 & 109 & 26.72 & \\
\hline Other & 8 & 3.7 & 5 & 2.6 & 13 & 3.19 & \\
\hline Total & 216 & 100 & 192 & 100 & 408 & 100.00 & \\
\hline
\end{tabular}

Table 3: The Future career choice preferred after graduation

\begin{tabular}{|c|c|c|c|c|c|c|c|}
\hline \multirow{4}{*}{$\begin{array}{c}\text { What is Future career } \\
\text { choice you prefer after } \\
\text { graduation? }\end{array}$} & \multicolumn{7}{|c|}{$(n=238)}$. \\
\hline & \multirow{2}{*}{\multicolumn{2}{|c|}{$\begin{array}{c}\text { Ger } \\
\text { Male }\end{array}$}} & \multirow{2}{*}{\multicolumn{2}{|c|}{ Female }} & \multirow{2}{*}{\multicolumn{2}{|c|}{ Total }} & \multirow{3}{*}{$P$-value } \\
\hline & & & & & & & \\
\hline & $N$ & $\%$ & \multicolumn{2}{|c|}{$N$} & $N$ & $\%$ & \\
\hline Hospital field & 69 & 56.6 & 63 & 54.3 & \multicolumn{2}{|c|}{\begin{tabular}{|l|l}
13255.46 \\
\end{tabular}} & \multirow{10}{*}{0.131} \\
\hline Community pharmacy & 5 & 4.01 & 0 & 0.00 & 5 & 2.10 & \\
\hline Pharmaceutical industry & 13 & 10.7 & 7 & 6 & 20 & 8.40 & \\
\hline $\begin{array}{l}\text { Pharmaceutical } \\
\text { company }\end{array}$ & 10 & 8.2 & 10 & 8.6 & 20 & 8.40 & \\
\hline Academia & 9 & 7.4 & 15 & 13 & 24 & 10.08 & \\
\hline Regulatory affairs & 2 & 1.6 & 2 & 1.7 & 4 & 1.68 & \\
\hline Enrolled in future study & 3 & 2.5 & 1 & 0.9 & 4 & 1.68 & \\
\hline $\begin{array}{c}\text { Other field than } \\
\text { pharmacy }\end{array}$ & 1 & 0.8 & 5 & 4.3 & 6 & 2.52 & \\
\hline Not sure yet & 10 & 8.2 & 13 & 11.2 & 23 & 9.66 & \\
\hline Total & 122 & 100 & 116 & 100 & 238 & 100 & \\
\hline
\end{tabular}




\section{International Journal of Science and Research (IJSR)}

ISSN: 2319-7064

Impact Factor (2018): 7.426

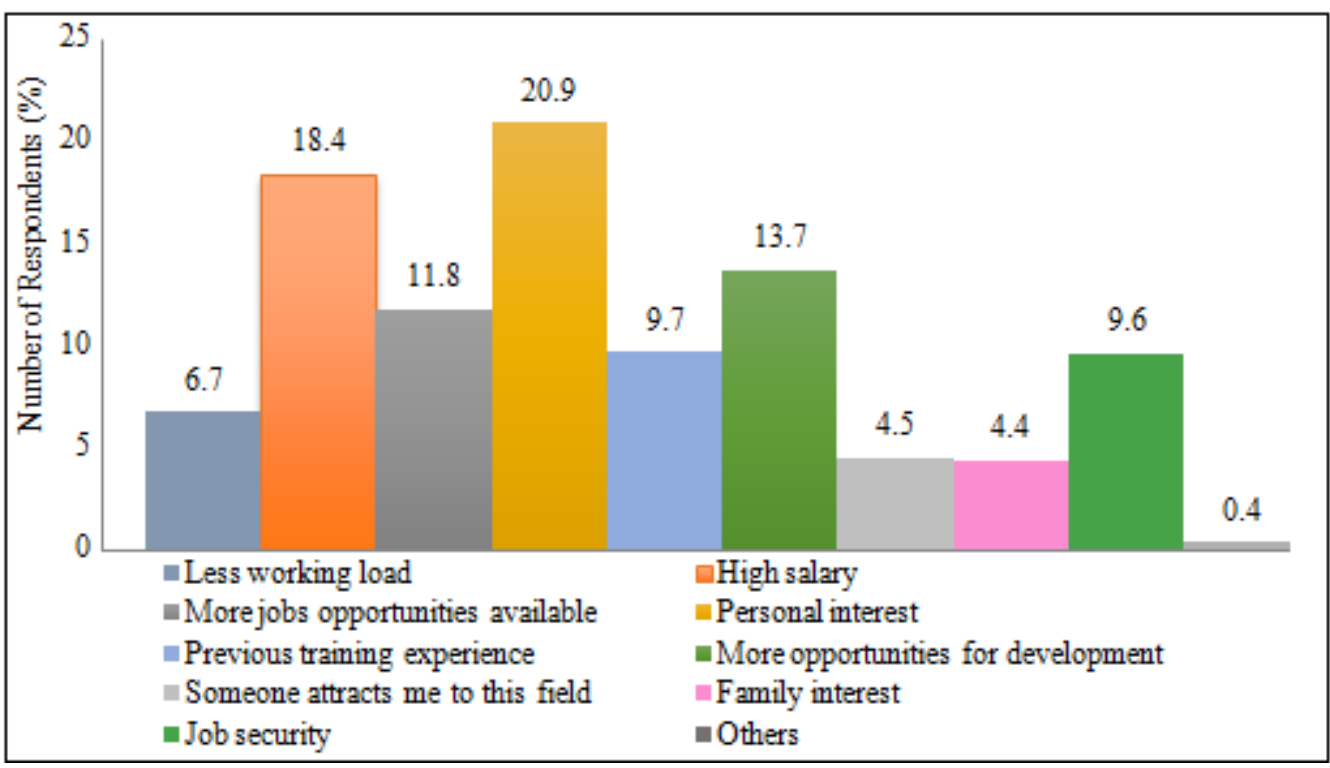

Figure 1: The factors that influence future career $\operatorname{choices}(\mathrm{n}=238)$.

Table 2: The Students' satisfaction about pharmacy profession $(n=238)$.

\begin{tabular}{|c|c|c|c|c|c|c|c|}
\hline \multirow[b]{2}{*}{ If I could do the choice again I will select the same pharmacy profession } & \multicolumn{4}{|c|}{ Gender } & \multirow[b]{2}{*}{$\begin{array}{c}\text { Total } \\
\mathrm{N}\end{array}$} & \multirow[b]{2}{*}{$\begin{array}{c}\text { Total } \\
\%\end{array}$} & \multirow[b]{2}{*}{ P-value } \\
\hline & $\begin{array}{c}\text { Male } \\
\mathrm{N}\end{array}$ & $\%$ & $\begin{array}{c}\text { Female } \\
\mathrm{N}\end{array}$ & $\%$ & & & \\
\hline Strongly disagree & 17 & 14 & 8 & 6.9 & 25 & 10.50 & \multirow{5}{*}{$0.032 *$} \\
\hline Disagree & 22 & 18 & 11 & 9.5 & 33 & 13.87 & \\
\hline Neutral & 29 & 23.7 & 23 & 19.8 & 52 & 21.85 & \\
\hline Agree & 37 & 30.3 & 51 & 44 & 88 & 36.97 & \\
\hline Strongly agree & 17 & 14 & 23 & 19.8 & 40 & 16.81 & \\
\hline \multicolumn{8}{|l|}{ I am proud of pharmacy career } \\
\hline Strongly disagree & 4 & 3.3 & 4 & 3.4 & 8 & 3.36 & \multirow{5}{*}{0.073} \\
\hline Disagree & 10 & 8.2 & 5 & 4.3 & 15 & 6.30 & \\
\hline Neutral & 25 & 20.5 & 13 & 11.2 & 38 & 15.97 & \\
\hline Agree & 48 & 39.3 & 43 & 37.1 & 91 & 38.24 & \\
\hline $\begin{array}{l}\text { Strongly agree } \\
\end{array}$ & 35 & 28.7 & 51 & 44 & 86 & 36.13 & \\
\hline \multicolumn{8}{|l|}{ I am happy that I have entered pharmacy school } \\
\hline Strongly disagree & 10 & 8.2 & 4 & 3.4 & 14 & 5.88 & \multirow{5}{*}{0.089} \\
\hline Disagree & 14 & 11.5 & 11 & 9.5 & 25 & 10.50 & \\
\hline Neutral & 29 & 23.7 & 21 & 18.1 & 50 & 21.01 & \\
\hline Agree & 51 & 41.8 & 48 & 41.4 & 99 & 41.60 & \\
\hline Strongly agree & 18 & 14.8 & 32 & 27.6 & 50 & 21.01 & \\
\hline Total & 122 & 100 & 116 & 100 & 238 & 100.0 & \\
\hline
\end{tabular}

Volume 8 Issue 3, March 2019 www.ijsr.net

Licensed Under Creative Commons Attribution CC BY 